\title{
Pengujian Peningkatan Kapasitas Lentur dengan Penambahan Dimensi pada Sisi Bawah dan Atas Balok Beton Bertulang
}

\author{
Samsuardi BATUBARA ${ }^{1 *}$, Martius GINTING $^{1}$, Francois SIREGAR ${ }^{1}$ \\ ${ }^{1}$ Program Studi Teknik Sipil, Universitas Katolik Santo Thomas, email: samsuardi_btbr@yahoo.com
}

\section{Sejarah artikel}

Diserahkan: $\quad 23$ Agustus 2021

Dalam bentuk revisi: 23 September 2021

\author{
Diterima: $\quad 28$ September 2021 \\ Tersedia online: $\quad 30$ September 2021
}

\begin{abstract}
This research aims to test the flexural capacity increase of a reinforced concrete beam after increasing the dimensions of the beam on the bottom and top sides. We used 3 specimens of reinforced concrete beams with a dimension of $150 \mathrm{~mm} \times 200 \mathrm{~mm}$, span of $3000 \mathrm{~mm}$. The first specimen was unreinforced, the second was reinforced by adding dimensions to the bottom side, and the third was reinforced by adding dimensions to the top side. With the addition of dimensions of $150 \mathrm{~mm} \times 100 \mathrm{~mm}$ with a span of $3000 \mathrm{~mm}$, the dimensions of the reinforcement test specimen become $150 \mathrm{~mm} x 300 \mathrm{~mm}$ with a span of $3000 \mathrm{~mm}$. For the unreinforced specimen, the load was applied with a hydraulic jack in the middle of the span and was loaded until the test specimen fails. Meanwhile, for the reinforced test specimen, the load was applied in two stages. The test results show that for the specimen with the addition of dimensions on the bottom side of the reinforced concrete beam, the flexural capacity increased by $211.84 \%$. Meanwhile, for the specimen with the addition of dimensions on the upper side, the flexural capacity increased by 192,98\% against the specimen without reinforcement. Based on the increase in flexure, it can be concluded that the addition of dimensions on the bottom side of the beam and on the bottom side of the reinforced concrete beam is safe to do.
\end{abstract}

Keywords: reinforced concrete beams, flexural capacity, reinforcement, beam dimensions

\begin{abstract}
Abstrak
Pengujian ini bertujuan untuk mengetahui besar peningkatan kapasitas lentur pada balok beton bertulang yang diperkuat dengan menambah dimensi balok pada sisi bawah dan sisi atasnya. Kami menggunakan 3 buah benda uji balok beton bertulang dengan dimensi $150 \mathrm{~mm} x 200 \mathrm{~mm}$ bentang $3000 \mathrm{~mm}$. Benda uji pertama adalah tanpa perkuatan, yang kedua adalah diperkuat dengan menambah dimensi pada sisi bawah, dan yang ketiga adalah diperkuat dengan menambah dimensi pada sisi atas. Dengan penambahan dimensi sebesar $150 \mathrm{~mm} \times 100 \mathrm{~mm}$ bentang $3000 \mathrm{~mm}$, dimensi benda uji perkuatan menjadi $150 \mathrm{~mm} \times 300 \mathrm{~mm}$ bentang $3000 \mathrm{~mm}$. Pemberian beban untuk benda uji tanpa perkuatan dilakukan dengan jack hidraulic pada tengah bentang dan dibebani hingga benda uji runtuh. Sementara, untuk benda uji dengan perkuatan pemberian beban dilakukan dengan dua tahap. Hasil pengujian menunjukkan bahwa untuk benda uji dengan penambahan dimensi pada sisi bawah balok beton bertulang, kapasitas lentur meningkat sebesar 211,84\%. Sedangkan, untuk benda uji dengan penambahan dimensi pada sisi atas kapasitas lentur meningkat sebesar 192,98\% terhadap benda uji tanpa perkuatan. Berdasarkan peningkatan lentur tersebut dapat disimpulkan bahwa penambahan dimensi pada sisi bawah balok maupun pada sisi bawah balok beton bertulang aman untuk dilakukan.
\end{abstract}

Kata kunci: balok beton bertulang, kapasitas lentur, perkuatan, dimensi balok 


\section{Pendahuluan}

Perkembangan dunia konstruksi semakin pesat seiring kemajuan teknologi, berdiri bangunanbangunan tinggi dengan bentang lebar diakibatkan oleh terbatas dan mahalnya lahan. Disamping perkembangan dunia konstruksi yang begitu pesat, perbaikan \& perkuatan struktur juga marak ditemui. Perbaikan dan perkuatan umumnya diawali dengan melakukan assessment terhadap struktur bangunan guna memetakan kerusakannya (Melchers, 2001). Perbaikan dan perkuatan struktur dilakukan akibat beberapa hal antara lain :

- Kesalahan pada saat pelaksanaan

Kesalahan pada saat pelaksanaan sering terjadi misalnya mutu beton yang tidak sesuai dengan mutu rencana.

- Kesalahan perencanaan

Kesalahan perencanaan bisa pada saat input beban - beban yang bekerja atau kesalahan dalam penggambaran struktur.

- Perubahan fungsi

Fungsi rumah toko menjadi kantor atau penambahan jumlah tingkat misalnya dari 3 tingkat menjadi 4 atau 5 tingkat

- Penambahan beban kerja yang tidak direncanakan pada saat perencanaan.

Penambahan beban kerja yang tidak direncanakan marak kita temui pada pembangunan mini tower telekomunikasi pada roof top berupa mini tower atau pole seperti Gambar 1.

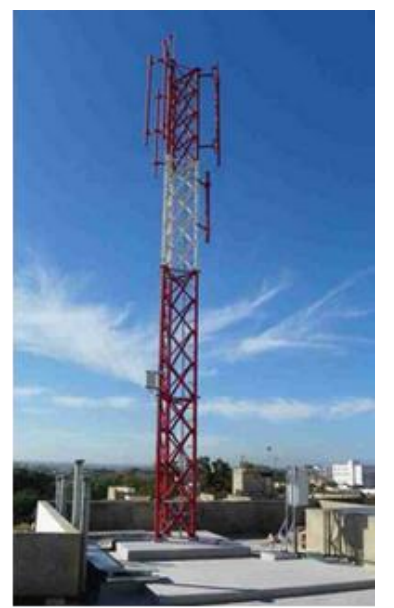

Gambar 1. Pembangunan Mini Tower Pada Roof Top (troynoya.com)

Kerusakan struktur dapat terjadi pada fase konstruksi maupun pasca konstruksi. Faktor yang umumnya muncul di pasca konstruksi adalah seperti: persoalan pelepasan bekisting, mengenai curing, dan juga tentang beban tambahan (Saputra, dkk., 2014). Ada beberapa metode dan material perkuatan yang umum dilakukan:

a. Memperpendek bentang, yakni memperpendek bentang dengan memberi support atau kolom dari beton atau baja, sehingga kemampuan dalam memikul gaya yang bekerja struktur meningkat.

b. Perkuatan dengan pelat baja, dimana yang dimaksudkan untuk meningkatkan kapasitas lentur dan geser balok dengan menempel pelat baja pada sisi bawah atau atas balok beton.

c. Perkuatan fiber reinforced polimer, yang mana belakangan ini umum dilakukan. Prinsipnya sama dengan perkuatan pelat baja.

d. Memperbesar dimensi, baik balok ataupun kolom eksisting, yakni dengan metode konvensional dengan menambah tulangan dan cor atau dengan menggunakan material yang bisa memadat sendiri.

Pemilihan metode tentu sangat dipengaruhi oleh biaya dan kemudahan pelaksanaan, sesuai prinsip teknik sipil aman dan ekonomis. Pengujian peningkatan kapasitas lentur sebenarnya sudah banyak dilakukan peneliti sebelumnya dengan material dan metode yang berbeda. 
Pengujian yang dilakukan antara lain seperti peningkatan kapasitas lentur dengan perkuatan pelat baja (Hutauruk, 2012), dengan perkuatan FRP (Sihombing, 2012), dengan penambahan tulangan menggunakan perekat Epoxy (Iswari, 2004), dan penggunaan Carbon Fiber Reinforced Polymer (CFRP) berlapis banyak (Sumargo \& Ruslan, 2014). Selain itu, diketahui bahwa penambahan dimensi untuk tujuan perkuatan yang dilakukan dengan metode jacketing cukup efektif untuk meningkatkan kapasitas balok (Sudarsana, dkk., 2010). Penelitian ini bertujuan untuk mendapatkan metode pelaksanan yang mudah dengan biaya yang relatif murah untuk peningkatan kapasitas lentur yang dimaksud.

\section{Beton Bertulang}

\section{Kuat Lentur Balok Persegi}

Beton bertulang adalah kombinasi beton dengan tulangan baja, dimana kedua elemen tersebut bekerja bersama untuk memikul beban. Tulangan baja pada prinsipnya memberikan karakteristik kuat tarik yang tidak ada pada beton. Selain itu, tulangan baja juga dapat memikul beban tekan, yang dapat dilihat aplikasinya di elemen kolom beton (Setiawan, 2016; SNI 2847, 2013).

Bila suatu penampang beton bertulang yang dibebani lentur murni dianalisis, pertama-tama perlu dipakai sejumlah kriteria agar penampang itu mempunyai probabilitas keruntuhan yang layak pada keadaan batas hancur. Penampang yang dianalisis mempunyai pengaruh yang sangat besar pada suatu prosedur atau anggapan dasar tertentu yang disepakati mempunyai ada probabilitas keruntuhan yang tertentu pula (Vis \& Kusuma, 1993).

Anggapan-anggapan yang digunakan dalam menganalisis beton bertulang yang diberi beban lentur murni adalah (Vis \& Kusuma, 1993):

- Beton tidak dapat menerima gaya tarik karena beton tidak mempunyai kekuatan tarik.

- Perubahan bentuk tanpa berupa pertambahan panjang dan perpendekan (regangan tarik dan tekan) pada serat-serat penampang, berbanding lurus dengan jarak tiap serat kesumbu netral. Ini merupakan kriteria yang kita kenal, yaitu penampang bidang datar akan tetap berupa bidang datar.

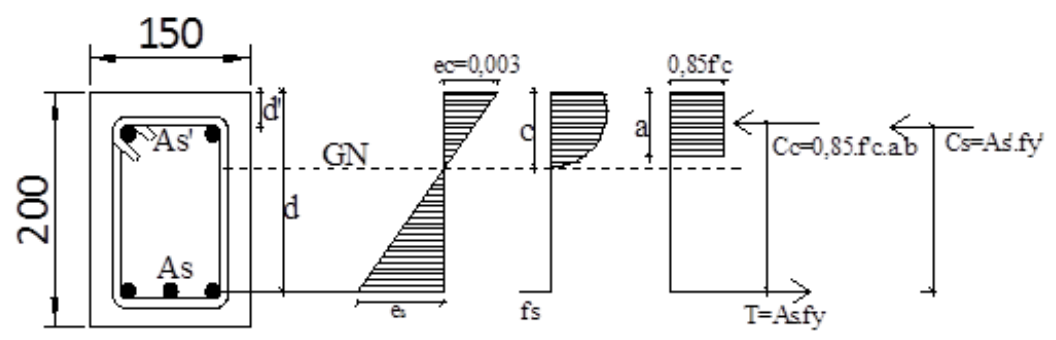

(a)

(b)

(c)

Gambar 2. Diagram tegangan tanpa perkuatan (a) penampang potongan; (b) diagram regangan kuat batas;

(c) kopel momen beton-baja

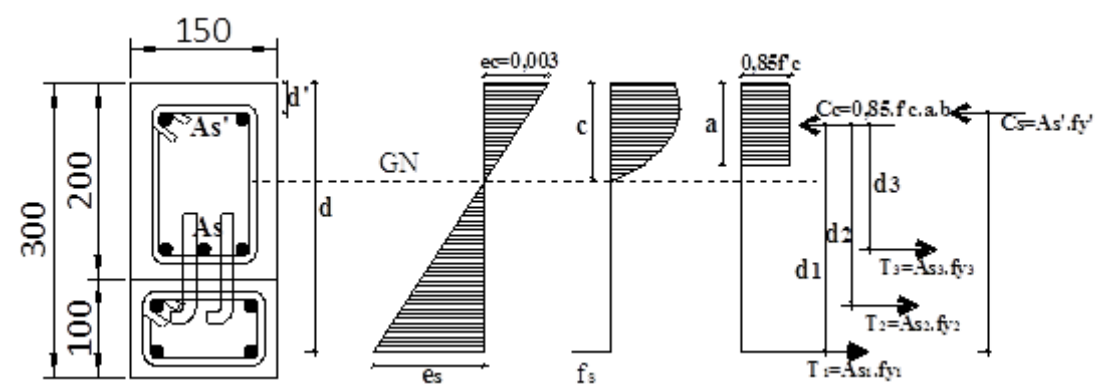

(a)

(b)

(c)

Gambar 3. Diagram tegangan dengan perkuatan sisi bawah balok (a) penampang potongan; (b) diagram regangan kuat batas; (c) kopel momen beton-baja 


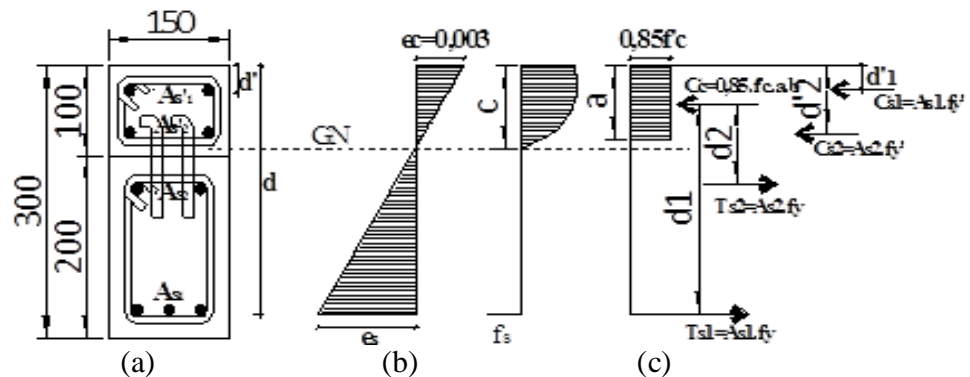

Gambar 4. Diagram tegangan dengan perkuatan sisi atas balok (a) penampang potongan; (b) diagram regangan kuat batas; (c) kopel momen beton-baja

Hubungan antara tegangan $(\sigma s)$ dan regangan ( $\varepsilon s)$ dapat dinyatakan secara skematis. Untuk tujuan penyederhanaan, Whitney (1942) telah mengusulkan bentuk persegi panjang sebagai distribusi tegangan tekan beton ekivalen seperti ditunjukkan Gambar 2.

Adapun flow chart untuk menghitung momen nominal dan kapasitas penampang secara teoritsi dapat dilihat pada Gambar 5.

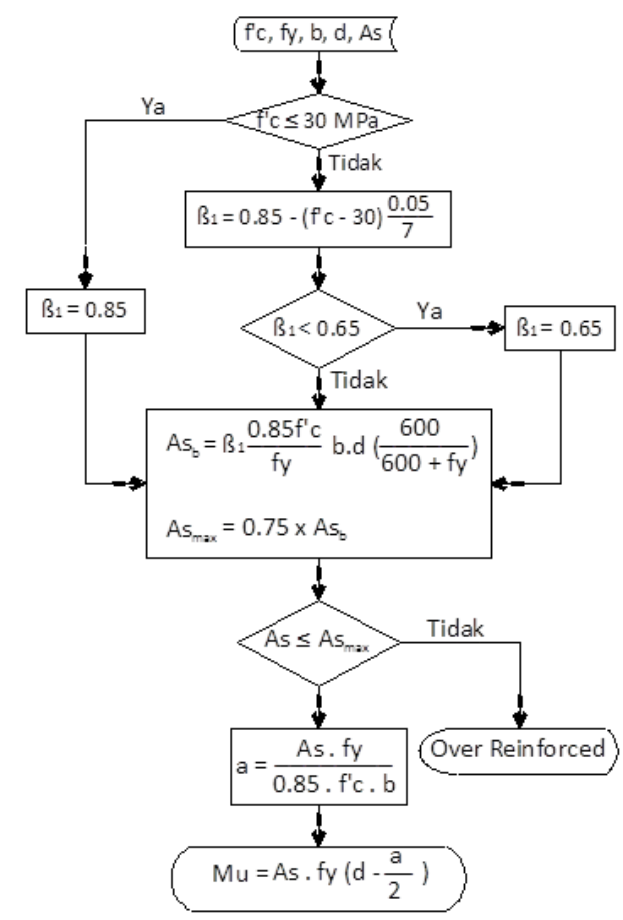

Gambar 5 Flow Chart Perhitungan Kapasitas Lentur

\section{Lendutan}

Lendutan yang terjadi akibat beban kerja adalah hal yang sangat penting dari struktur beton bertulang. Lentur yang bekerja harus direncanakan sedemikian rupa sehingga struktur mempunyai kekakuan untuk membatasi lendutan yang terjadi, sehinga lendutan yang terjadi tidak lebih besar dari lendutan izin. Sehubungan dengan lendutan tersebut maka besar lendutan yang terjadi sangat dipengaruhi oleh panjang bentang dan beban yang terjadi. Bila bentang panjang, maka lendutan akan besar. Untuk memperkecil lendutan biasanya diantisipasi dengan memperbesar kekakuan penampang (EI).

Secara mekanika, hubungan lendutan (v), kekakuan penampang (EI) dan momen lentur (M) adalah:

$$
\frac{d^{2} U}{d x^{2}}=\frac{M}{E I}
$$


Dengan persamaan differensial diatas, dapat dicari nilai lendutan di tengah bentang. Lendutan untuk balok yang ditumpu oleh tumpuan sederhana dengan beban terpusat di tengah bentang adalah:

$$
\delta=U \max =\frac{P L^{3}}{48 E I}
$$

Pada dasarnya untuk menghindari keruntuhan, lendutan yang terjadi dibatasi oleh lendutan ijin maksimum, yaitu tidak boleh lebih besar dari L/240.

\section{Metodologi}

Adapun flow chart penelitian ini disajikan sebagai berikut:

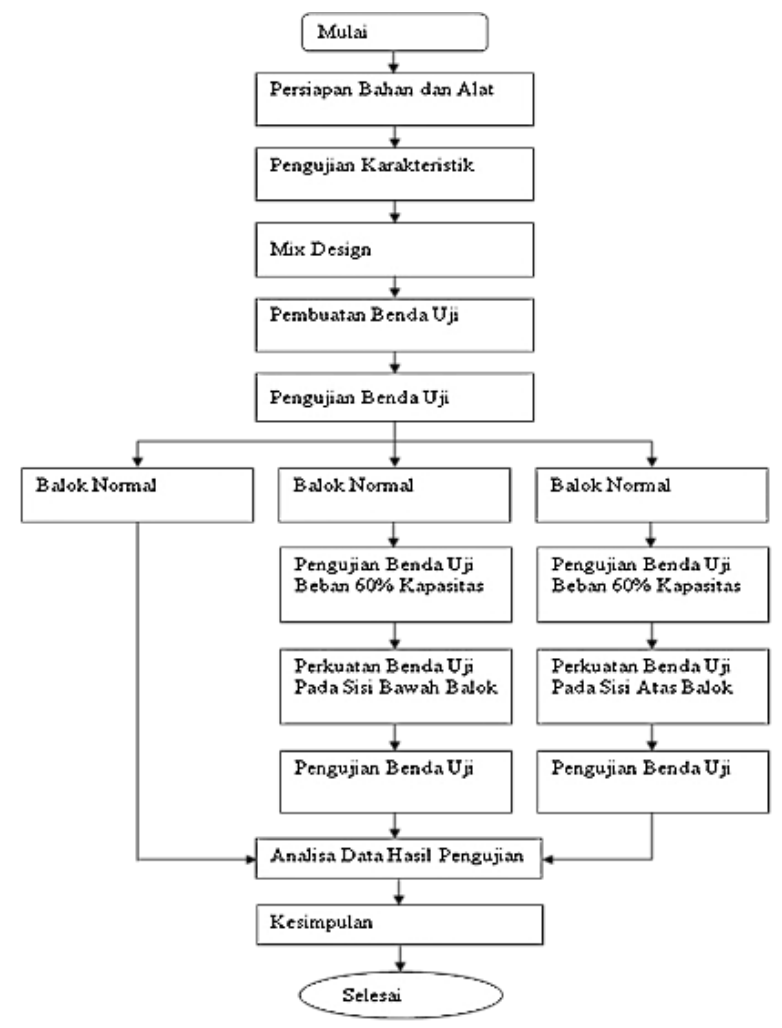

Gambar 6 Flow Chart Penelitian

\section{Mutu Material dan Peralatan Pengujian}

Beton yang digunakan adalah site mix. Berdasarkan hasil pengujian, mutu beton adalah $\mathrm{fc}^{\prime}=22,76 \mathrm{MPa}$ dan mutu tulangan $\varnothing 8$ untuk sengkang fy $=570,77 \mathrm{MPa}$, dan D13 untuk tulangan logitudinal fy $=471,66 \mathrm{MPa}$, shear connector dengan D13 fy $=471,66 \mathrm{MPa}$. Jumlah sampel benda uji adalah 3 (tiga) buah dengan dimensi 150/200 mm dengan bentang 3000 $\mathrm{mm}$.

Adapun peralatan utama untuk penelitian antara lain :

a) Loading Frame, digunakan sebagai perletakan balok untuk uji lentur balok.

b) Hydraulic Jack, digunakan sebagai pemberi beban pada benda uji balok.

c) Dial, digunakan untuk membaca penurunan yang terjadi.

\section{Pengujian Benda Uji (28 hari)}

\section{Pengujian Benda Uji Tanpa Perkuatan}

Benda uji tanpa perkuatan di beri beban dengan bantuan jack hydraulic. Pemberian beban dimulai dari beban kecil dan perlahan-lahan dinaikkan hingga benda uji runtuh. 


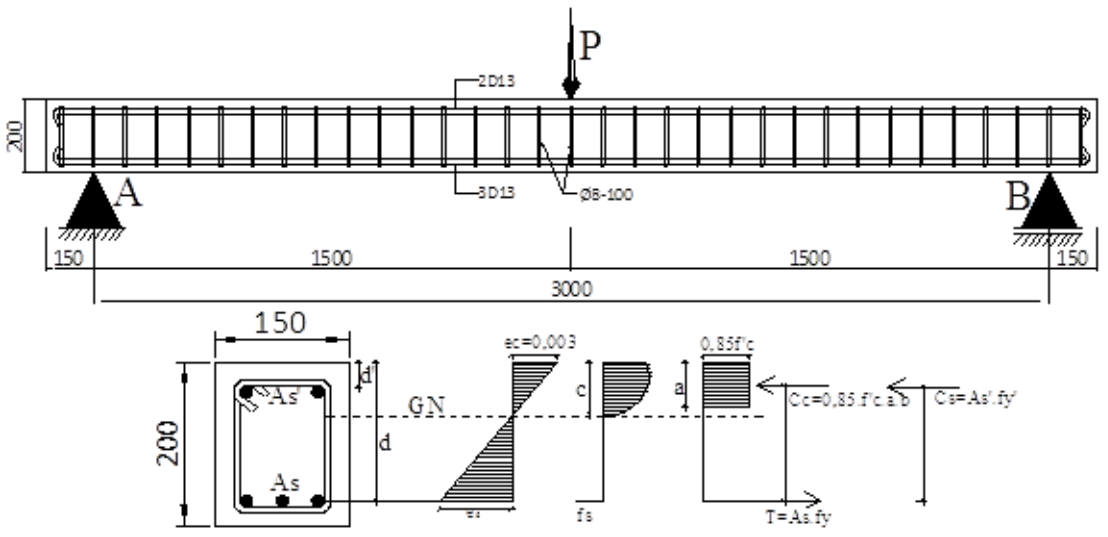

(a)

(b)

(c)

Gambar 7. Benda uji tanpa perkuatan (a) penampang potongan; (b) diagram regangan kuat batas; (c) kopel momen beton-baja

\section{Benda Uji Perkuatan Sisi Bawah Balok}

Benda uji kedua dengan dimensi sama dengan tanpa perkuatan dibebani hingga $60 \%$ beban rencana, pemberian beban sebesar $60 \%$ dimaksudkan untuk mengkondisikan benda uji telah dibebani sebelum diperkuat selanjutnya benda uji diperkuat pada sisi bawah, setelah perkuatan berumur 28 hari dilakukan pengujian kembali hingga benda uji runtuh.

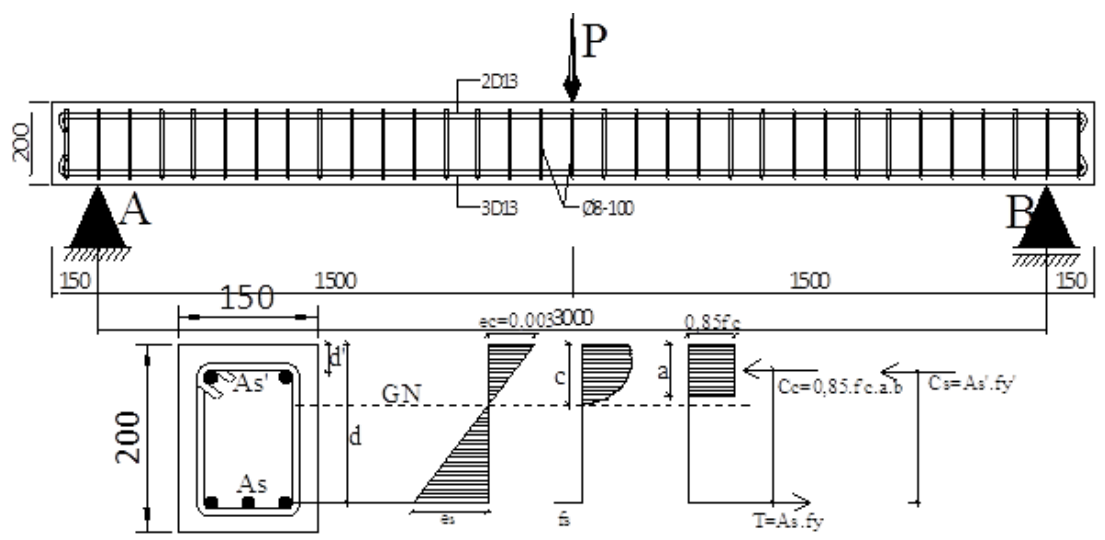

(a)

(b)

(c)

Gambar 8. Benda uji dibebani $60 \%$ beban rencana kemudian diperkuat pada sisi bawah (a) penampang potongan; (b) diagram regangan kuat batas; (c) kopel momen beton-baja

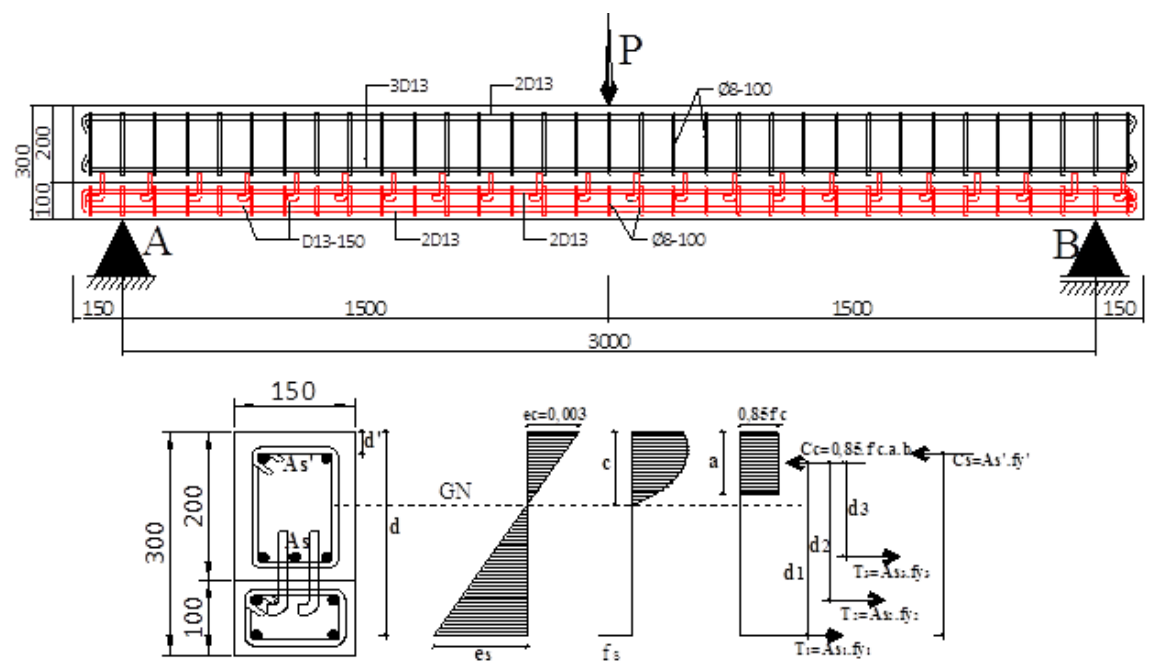

(a)

(b)

(c)

Gambar 9. Benda uji perkuatan pada sisi bawah balok (a) penampang potongan; (b) diagram regangan kuat batas; (c) kopel momen beton-baja 


\section{Benda Uji Perkuatan Sisi Atas Balok}

Benda uji ketiga dengan dimensi sama dengan tanpa perkuatan dibebani hingga $60 \%$ beban rencana, pemberian beban sebesar $60 \%$ dimaksudkan untuk mengkondisikan benda uji telah dibebani sebelum diperkuat selanjutnya benda uji diperkuat pada sisi atas, setelah perkuatan berumur 28 hari dilakukan pengujian kembali hingga benda uji runtuh.

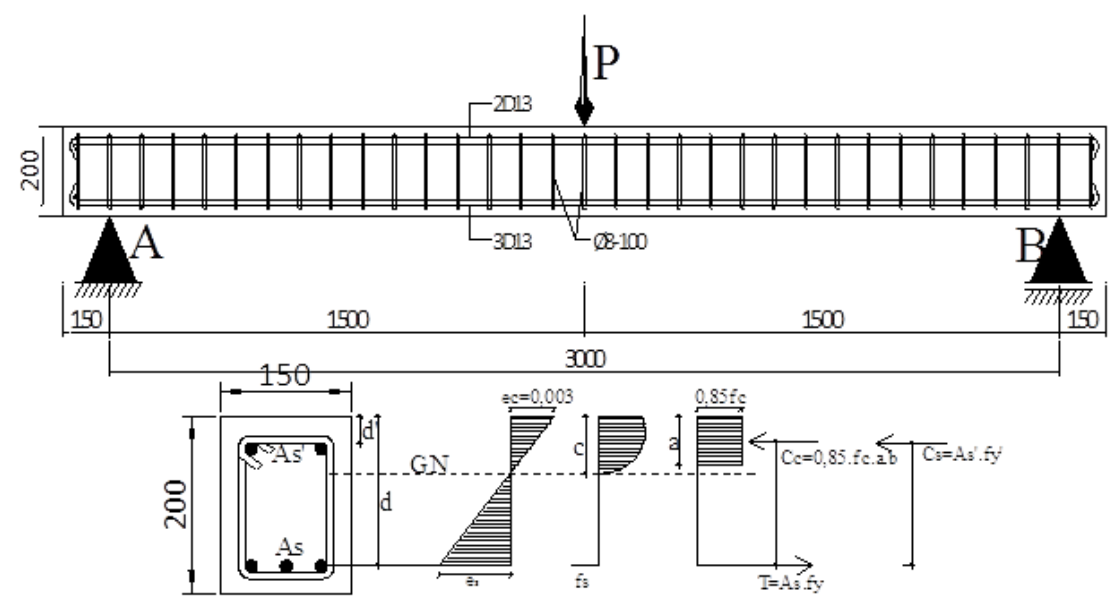

(a)

(b)

(c)

Gambar 10. Benda uji dibebani $60 \%$ beban rencana kemudian diperkuat pada sisi atas balok (a) penampang potongan; (b) diagram regangan kuat batas; (c) kopel momen beton-baja
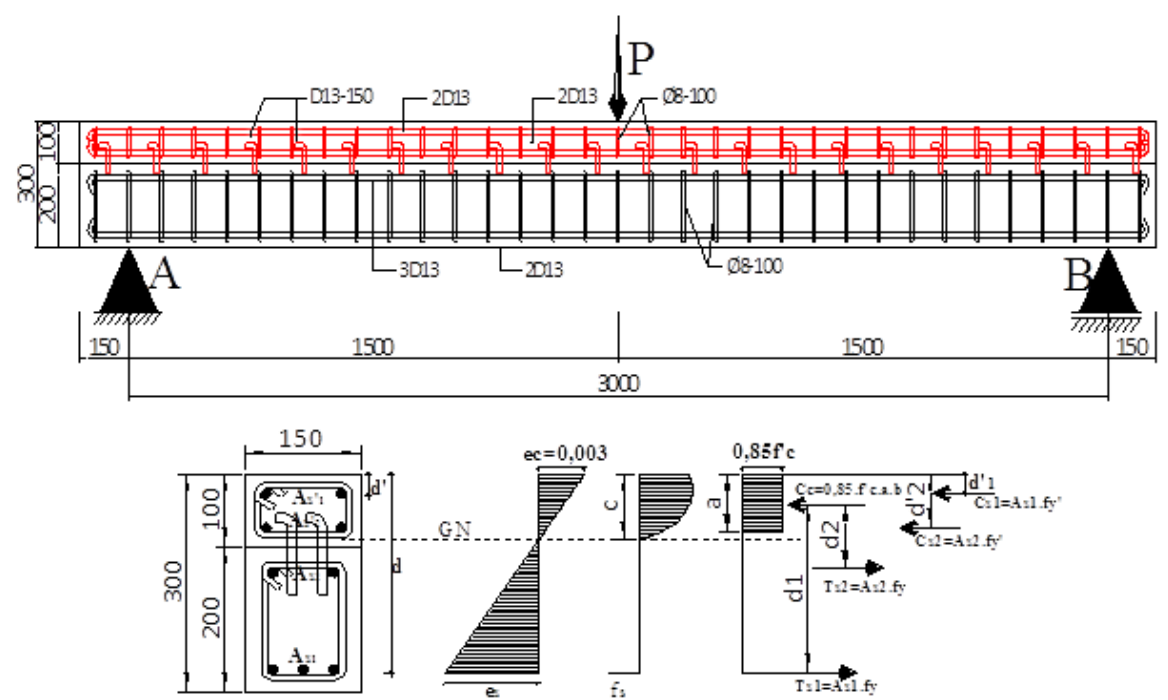

(a)

(b)

(c)

Gambar 11. Benda uji Perkuatan pada sisi atas (a) penampang potongan; (b) diagram regangan kuat batas; (c) kopel momen beton-baja

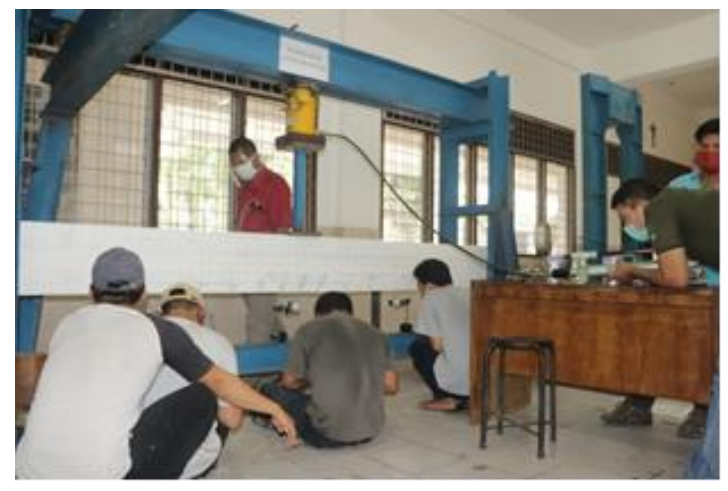

Gambar 12. Set-up pengujian benda uji 


\section{Hasil dan Pembahasan}

\section{Kapasitas Lentur Teoritis}

Berdasarkan perhitungan teoritis diperoleh kapasitas lentur seperti Tabel 1.

Tabel 1 Kapasitas Lentur Secara Teoritis

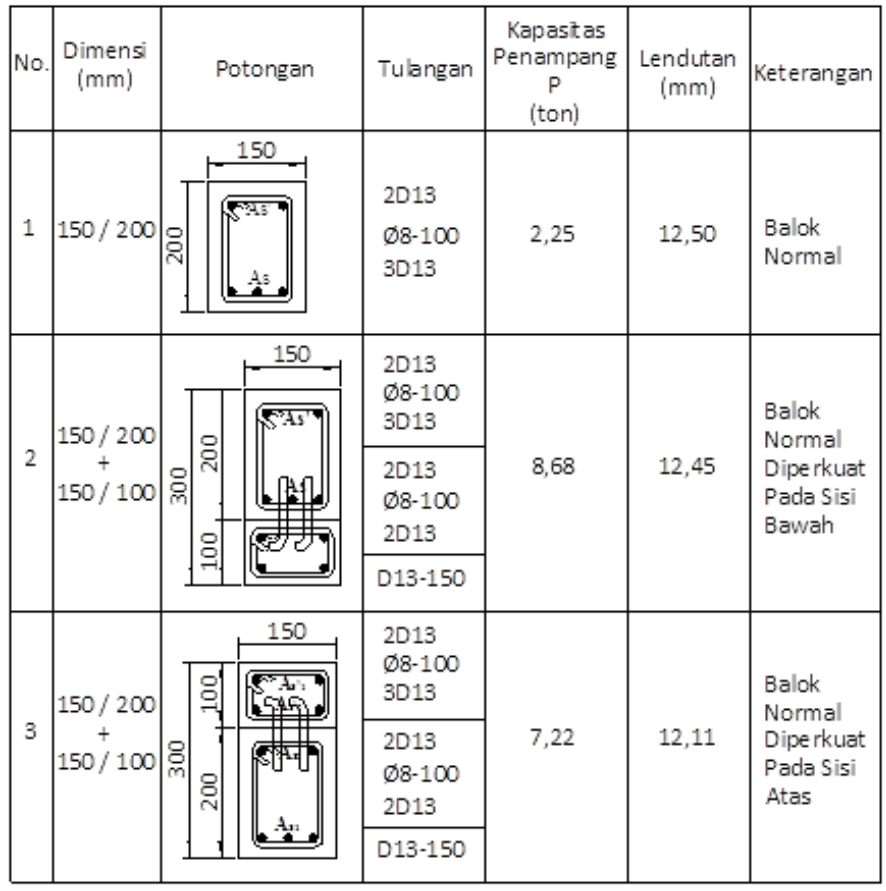

\section{Hasil Pengujian}

Pengujian lentur diperoleh berupa beban, lendutan dan retak. Pemberian beban dilakunan dengan jack hidraulic pada tengah bentang dan lendutan yang terjadi pada tengah bentang yang dibaca pada dial pembacaan penuruan. Adapun grafik hubungan beban terhadap penurunan dapat dilihat pada Grafik 1.

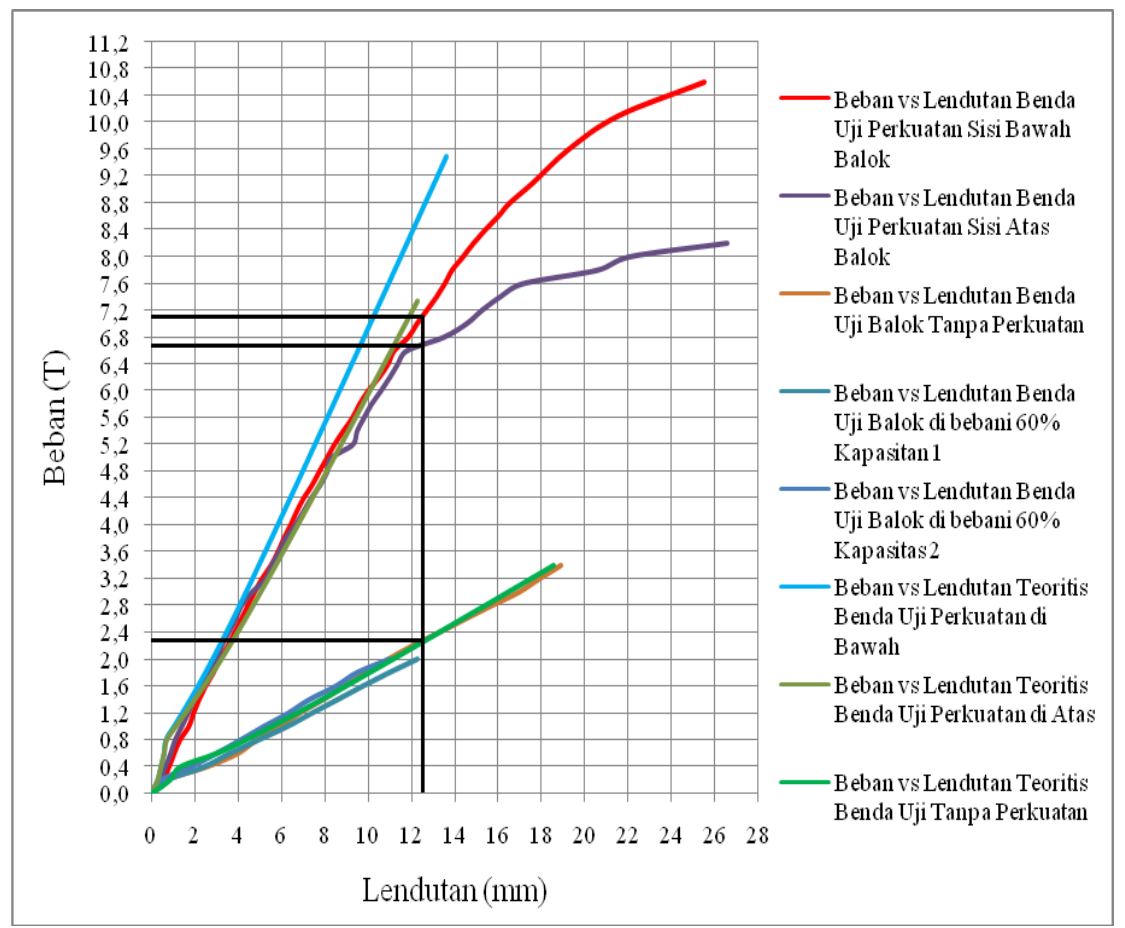

Gambar 13. Hubungan beban-lendutan secara teoritis dan hasil pengujian untuk balok normal, pembebanan $60 \%$ dari kapasitas rencana, perkuatan pada sisi bawah, perkuatan pada sisi atas 
Sementara itu, hasil pengujian dapat dilihat pada Tabel 2.

Tabel 2 Hasil Pengujian Kapasitas Lentur

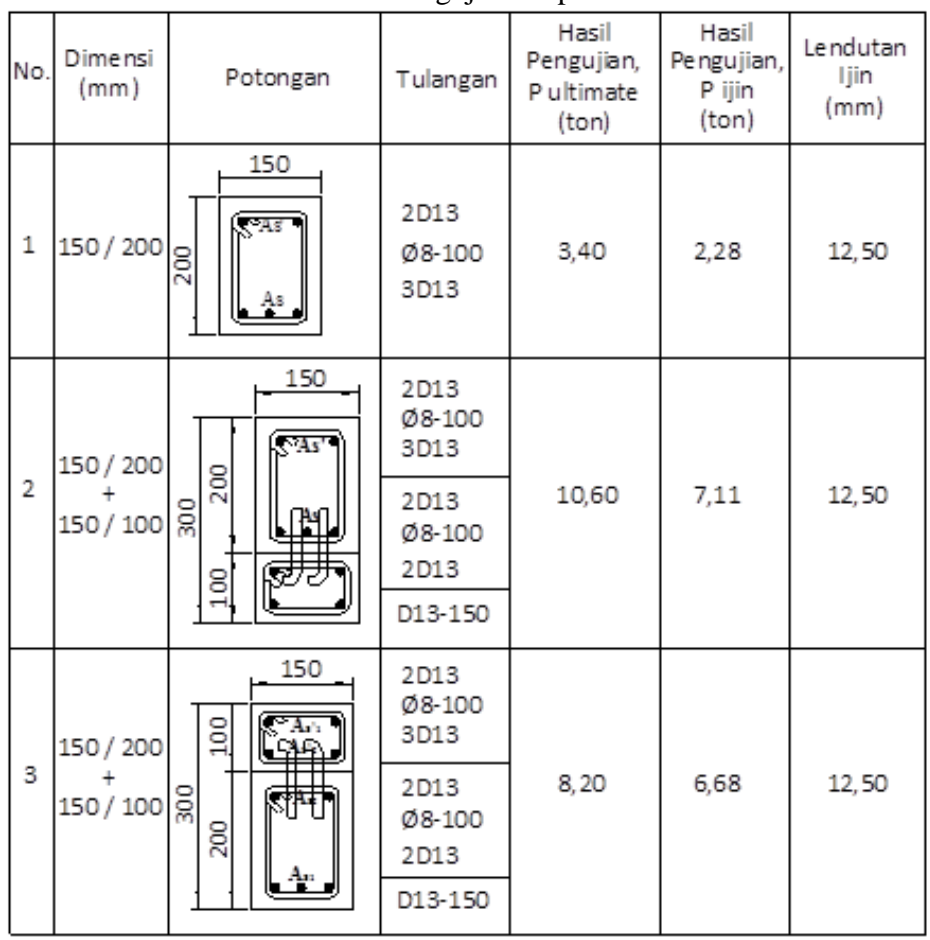

Tabel 3. Kapasitas lentur berdasarkan teoritis dan hasil pengujian

\begin{tabular}{|c|c|c|c|c|c|c|c|}
\hline \multirow[t]{2}{*}{ No. } & $\begin{array}{c}\text { Dimensi } \\
(\mathrm{mm})\end{array}$ & \multicolumn{2}{|r|}{ Potongan } & Tulangan & \begin{tabular}{|c|} 
Kapasitas \\
Penampang \\
Teoritis, \\
P ijin (ton)
\end{tabular} & \begin{tabular}{|c|} 
Kapasitas \\
Penampang \\
Pengujian, \\
P ijin (ton)
\end{tabular} & $\begin{array}{c}\text { Le ndutan } \\
\text { Ijin } \\
(\mathrm{mm})\end{array}$ \\
\hline & $150 / 200$ & 이 & 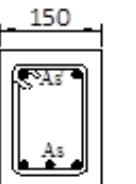 & $\begin{array}{l}2 \mathrm{D} 13 \\
\emptyset 8-100 \\
3 \mathrm{D} 13\end{array}$ & 2,25 & 2,28 & 12,50 \\
\hline \multirow{3}{*}{2} & \multirow{3}{*}{$\begin{array}{c}150 / 200 \\
+ \\
150 / 100\end{array}$} & & 150 & $\begin{array}{l}2 \mathrm{D} 13 \\
\varnothing 8-100 \\
3 \mathrm{D} 13\end{array}$ & \multirow{3}{*}{8,68} & \multirow{3}{*}{7,11} & \multirow{3}{*}{12,50} \\
\hline & & & \multirow{2}{*}{ 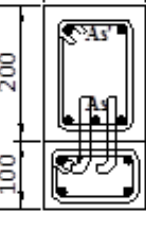 } & $\begin{array}{l}2 \mathrm{D} 13 \\
\emptyset 8-100 \\
2 \mathrm{D} 13\end{array}$ & & & \\
\hline & & & & D13-150 & & & \\
\hline \multirow{4}{*}{3} & \multirow{4}{*}{$\left|\begin{array}{c}150 / 200 \\
+ \\
150 / 100\end{array}\right|$} & \multirow{4}{*}{\multicolumn{2}{|c|}{150}} & $2 \mathrm{D} 13$ & \multirow{4}{*}{7,22} & \multirow{4}{*}{6,68} & \multirow{4}{*}{12,50} \\
\hline & & & & $\begin{array}{l}\emptyset 8-100 \\
3 D 13\end{array}$ & & & \\
\hline & & & & $\begin{array}{l}2 \mathrm{D} 13 \\
\emptyset 8-100 \\
2 \mathrm{D} 13\end{array}$ & & & \\
\hline & & & & D13-150 & & & \\
\hline
\end{tabular}

Berdasarkan Tabel 3, kapasitas lentur secara teoritis dan pengujian untuk benda uji tanpa perkuatan relatif sama. Sedangkan, untuk benda uji perkuatan pada sisi bawah dan sisi atas kapasitas lentur secara teoritis lebih besar dibandingkan hasil penelitian. Perbedaan diakibatkan adanya slip pada pertemuan beton lama dengan beton perkuatan, hal tersebut diakibatkan oleh shear connector yang tidak bekerja sempurna. Foto dokumentasi dapat dilihat pada Gambar 13. 

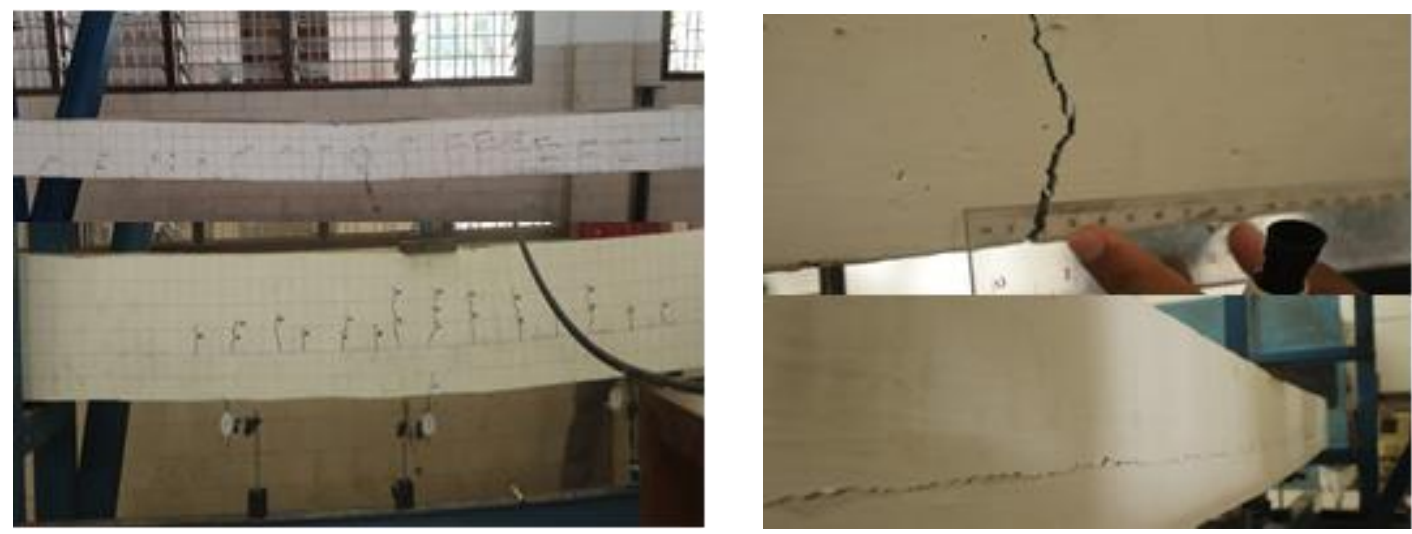

Gambar 14. Foto pengujian benda uji

\section{Diskusi dan Pembahasan}

Kapasitas penampang teorits dibandingkan hasil pengujian relatif sama, peningkatan kapasitas lentur perkuatan pada sisi bawah meningkat sebesar 211,84\% sementara untuk perkuatan pada sisi atas meningkat $192,98 \%$. Hasil penelitian ini senada dengan yang penelitian yang pernah dilakukan Hutauruk (2012) dimana perkuatan dilakukan pada sisi bawah dengan benda uji dimensi 200x300 mm dan panjang 3000mm. Perkuatan menggunakan pelat baja dengan dimensi lebar 200 tebal $3 \mathrm{~mm}$ dan panjang $2400 \mathrm{~mm}$. Diperoleh peningkatan sebesar $77,78 \%$. Selanjutnya, penelitian lain adalah Sumargo \& Ruslan (2014) dengan dimensi benda uji 100/150 mm panjang $750 \mathrm{~mm}$. Peningkatan kemampuan beton dalam menerima beban bertambah secara linier hingga CFRP lapis 3 dan berkurang kembali pada lapis 4 dan 5 . Perbandingan kekuatan terhadap beton normal adalah CFRP 1 lapis 133\%, CFRP 2 lapis 166\%, CFRP 3 lapis 200\%, CFRP 4 lapis 166\% dan CFRP 5 lapis $183 \%$. Peningkatan kapasitas lentur penambahan dimensi balok, penambahan pelat baja maupun penggunaan CFRP sangat signifikan. Dengan demikian, perlakuan ini aman untuk dilakukan.

\section{Kesimpulan dan Saran}

Berdasarkan hasil analisa penampang secara teroritis dan hasil pengujian dan pembahasan yang dilakukan maka dapat diambil beberapa kesimpulan sebagai berikut:

- Peningkatan kapasitas lentur benda uji balok normal terhadap benda uji balok diperkuat pada sisi bawah pada lendutan izin sebesar $12,5 \mathrm{~mm}$, berdasarkan hasil pengujian meningkat sebesar 211,84\%.

- Peningkatan kapasitas lentur benda uji balok normal terhadap benda uji diperkuat pada sisi atas balok pada lendutan ijin sebesar $12,5 \mathrm{~mm}$, berdasarkan hasil pengujian meningkat sebesar 192,98\%.

- Perkuatan balok baik pada sisi bawah maupun pada sisi atas aman untuk dilakukan

Berdasarkan hasil penelitian, dapat disarankan bahwa untuk memperoleh hasil yang lebih akurat, perlu kiranya penambahan balok uji sebagai syarat statistik untuk mengambil kesimpulan. Jack hydraulic sebagai alat pengujian beban, diharapkan memiliki kapasitas/kemampuan skala pembacaan beban yang lebih detail dan alat yang lebih canggih.

\section{Referensi}

Badan Standardisasi Nasional. (2013). SNI 2847-2013: Persyaratan beton struktural untuk bangunan gedung.

Hutauruk, K. (2012). Peningkatan Kapasitas lentur dengan Perkuatan Pelat Baja [Skripsi]. Universitas Katolik Santo Thomas.

Iswari, A. Y. D. (2004). Perkuatan Lentur Balok Tampang Persegi dengan Penambahan Tulangan Menggunakan Perekat Epoxy [Tesis]. Universitas Gadjah Mada.

Melchers, R. E. (2001). Assessment of existing structures-Approaches and research needs. Journal of Structural Engineering, 127(4), 406-411.

Saputra, A. G., Taran, R., Sudjarwo, P., \& Buntoro, J. (2014). Identifikasi Penyebab Kerusakan Pada 
Beton Dan Pencegahannya. Jurnal Dimensi Pratama Teknik Sipil, 3(2).

Setiawan, A. (2016). Perancangan struktur beton bertulang berdasarkan SNI 2847: 2013. Penerbit Erlangga.

Sihombing, B. (2012). Peningkatan Kapasitas Lentur Dengan Perkuatan FRP [Skripsi]. Universitas Katolik Santo Thomas.

Sudarsana, I. K., Sugupta, D. P. G., \& Kochiana, I. K. G. (2010). Efektivitas Jacketing Method Menggunakan Self Compacting Concrete (SCC) Untuk Perkuatan Balok T Beton Bertulang. Konferensi Nasional Teknik Sipil 4 (KoNTekS 4), 139-147.

Sumargo, S., \& Ruslan, U. (2014). Kapasitas Penggunaan Carbon Fiber Reinforced Polymer (Cfrp) Berlapis Banyak Terhadap Perkuatan Lentur Struktur Balok Beton Bertulang. Prosiding Industrial Research Workshop and National Seminar, 5, 126-133.

Vis, W. C., \& Kusuma, G. H. (1993). Dasar-dasar Perencanaan Beton Bertulang, Seri Beton I. Penerbit Erlangga.

Whitney, C. S. (1942). Plastic theory of reinforced concrete design. Transactions of the American Society of Civil Engineers, 107(1), 251-282. 


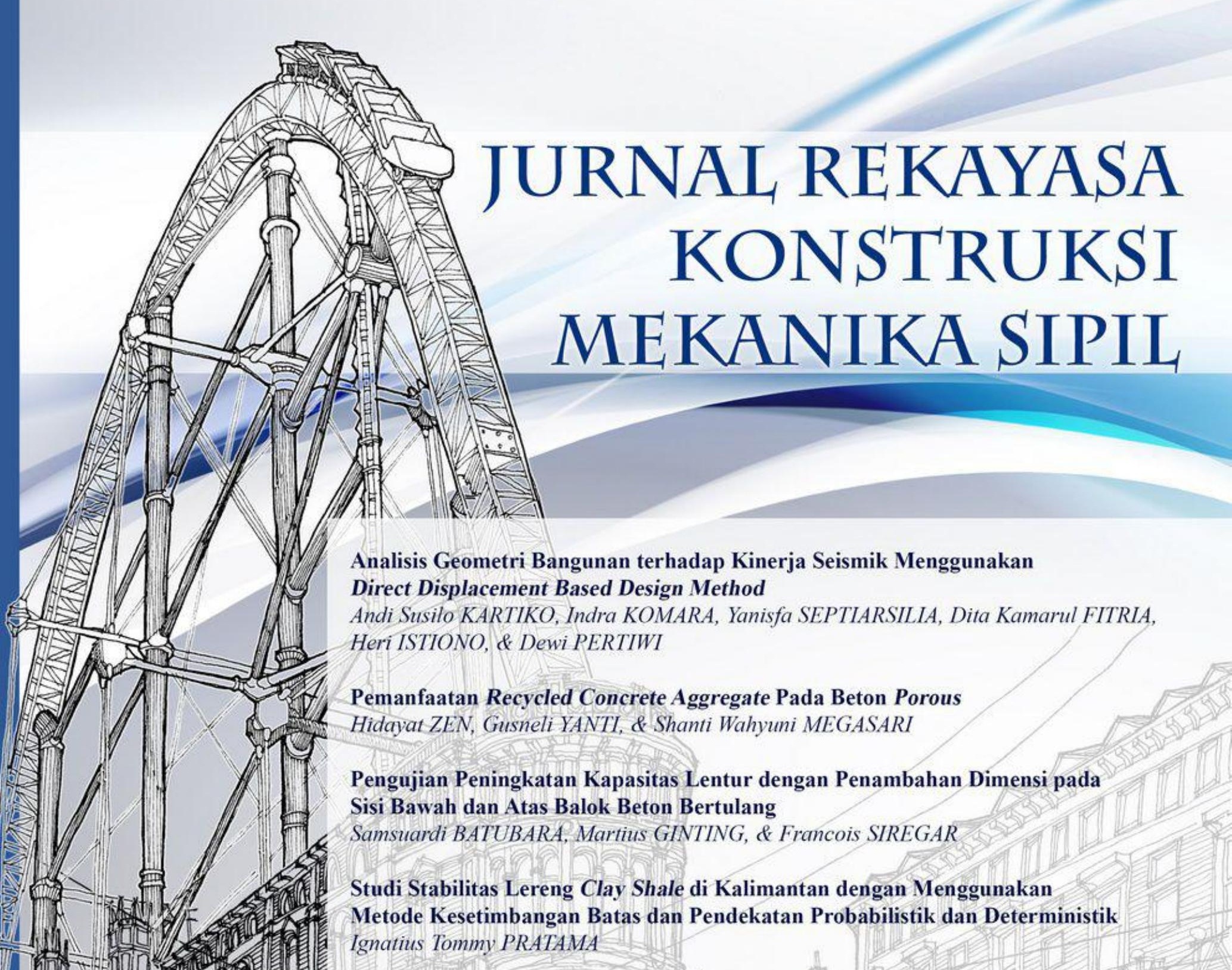

Pengaruh Tata Guna Lahan terhadap Kinerja Jalan dan Biaya Tundaan Lalu Lintas Koridor Jalan GOR Mustika Kabupaten Blora

Hartono Guntur RISTIYANTO \& Salma MFIRDAUS

Kinerja Moda Bus Trans Mebidang Trayek Lubuk Pakam-Pusat Pasar Medan di Masa Pandemi Covid-19

Oloan SITOHANG, Reynaldo SIAHAAN, \& Arnoldus Yansen Berkat LAIA

Perbandingan Produktivitas Tenaga Kerja Pembesian dan Bekisting Saat Jam Kerja Normal dan Lembur Menggunakan Metode Productivity Rating Caroline Maretha SUJANA \& Raka Aditya HAKIM

Analisis Faktor-Faktor yang Mempengaruhi Produktivitas Tenaga Kerja pada Proyek Pembangunan Jalan Tol Ruas Binjai-Langsa Seksi Binjai-Pangkalan Brandan Yolanda Ayu DAMAYANTI \& Mizanuddin SITOMPUL

Fakultas Teknik 


\section{Jurnal Rekayasa Konstruksi Mekanika Sipil (JRKMS)}

Jurnal Rekayasa Konstruksi Mekanika Sipil (JRKMS) Fakultas Teknik Universitas Katolik Santo Thomas berisi artikel-artikel ilmiah yang meliputi kajian di bidang teknik khususnya Teknik Sipil, seperti matematika teknik, mekanika teknik, analisis struktur, konstruksi baja, konstruksi beton, konstruksi kayu, konstruksi gelas, mekanika tanah, teknik pondasi, hidrologi, hidrolika, bangunan air, manajemen konstruksi, dinamika struktur, earthquake engineering, sistem dan rekayasa transportasi, ilmu ukur tanah, struktur bangunan sipil, rekayasa jalan raya, serta penelitian-penelitian lain yang terkait dengan bidang-bidang tersebut.

Terbit dalam 2 (dua) kali setahun yaitu pada bulan April dan September

\section{Penasihat :}

Prof. Dr. Drs. Sihol Situngkir, MBA. (Rektor Universitas Katolik Santo Thomas)

Ketua Penyunting (Editor in Chief) :

Ir. Oloan Sitohang, M.T. (Universitas Katolik Santo Thomas)

Manajer Penyunting (Managing Editor):

Reynaldo, S.T., M.Eng. (Universitas Katolik Santo Thomas)

\section{Anggota Penyunting (Editorial Board):}

Dr.-Ing. Sofyan S.T, M.T. (Universitas Malikussaleh)

Ir. Martius Ginting, M.T. (Universitas Katolik Santo Thomas)

Samsuardi Batubara, S.T., M.T. (Universitas Katolik Santo Thomas)

Dr. Janner Simarmata (Universitas Negri Medan)

\section{Mitra Bestari (Peer Reviewer):}

Dr.Eng. Ir. Aleksander Purba, S.T., M.T., IPM, ASEAN Eng. (Universitas Lampung, Indonesia)

Ir. Binsar Silitonga, M.T. (Universitas Katolik Santo Thomas, Indonesia)

Budi Hasiholan, S.T., M.T., Ph.D (Institut Teknologi Bandung, Indonesia)

Ir. Charles Sitindaon, M.T. (Universitas Katolik Santo Thomas, Indonesia)

Dr. Erica Elice Uy (De La Salle University, Philippines)

Dr. Ernesto Silitonga, S.T, D.E.A. (Universitas Negeri Medan, Indonesia)

Prof. Dr-Ing. Johannes Tarigan (Universitas Sumatera Utara, Indonesia)

Linda Prasetyorini (Universitas Brawijaya, Malang, Indonesia)

Dr.Eng. Mia Wimala (Universitas Katolik Parahyangan, Indonesia)

Dr.Eng. Minson Simatupang (Universitas Halu Oleo, Indonesia)

Dr. Mochamad Raditya Pradana (Keppel Marine and Deepwater Technology, Singapura)

Dr. Ir. Shirly Susanne Lumeno, S.T., M.T. (Universitas Negeri Manado, Indonesia)

Dr. Senot Sangadji (Universitas Sebelas Maret, Indonesia)

Ir. Simon Dertha, M.T. (Universitas Katolik Santo Thomas, Indonesia)

Dr. Thi Nguyên Cao (Tien Giang University, Viet Nam)

Budijanto Widjaja, S.T., M.T., Ph.D, (Guest Vol.4.No.2) (Universitas Katolik Parahyangan, Indonesia)

\section{Ilustrator Sampul:}

Yulianto, ST., M.Eng

\section{Penerbit \& Alamat Redaksi:}

Fakultas Teknik Universitas Katolik Santo Thomas

Jl. Setiabudi No. 479-F Tanjung Sari, Medan 20132

Telp. (061) 8210161 Fax : (061) 8213269

email : unika.sipil@yahoo.com 


\title{
Konten
}

\author{
REKAYASA STRUKTUR \\ Analisis Geometri Bangunan terhadap Kinerja Seismik Menggunakan \\ Direct Displacement Based Design Method \\ Andi Susilo KARTIKO, Indra KOMARA, Yanisfa SEPTIARSILIA, Dita Kamarul \\ FITRIA, Heri ISTIONO, \& Dewi PERTIWI
}

hal.

$73-84$

Pemanfaatan Recycled Concrete Aggregate Pada Beton Porous

Hidayat ZEN, Gusneli YANTI, \& Shanti Wahyuni MEGASARI

Pengujian Peningkatan Kapasitas Lentur dengan Penambahan Dimensi

pada Sisi Bawah dan Atas Balok Beton Bertulang

Samsuardi BATUBARA, Martius GINTING, \& Francois SIREGAR

\section{REKAYASA GEOTEKNIK}

Studi Stabilitas Lereng Clay Shale di Kalimantan dengan Menggunakan

Metode Kesetimbangan Batas dan Pendekatan Probabilistik dan

Deterministik

Ignatius Tommy PRATAMA

\section{REKAYASA TRANSPORTASI}

Pengaruh Tata Guna Lahan terhadap Kinerja Jalan dan Biaya Tundaan

Lalu Lintas Koridor Jalan GOR Mustika Kabupaten Blora

Hartono Guntur RISTIYANTO \& Salma M FIRDAUS

Kinerja Moda Bus Trans Mebidang Trayek Lubuk Pakam-Pusat Pasar

Medan di Masa Pandemi Covid-19

Oloan SITOHANG, Reynaldo SIAHAAN, \& Arnoldus Yansen Berkat LAIA

\section{MANAJEMEN KONSTRUKSI}

Perbandingan Produktivitas Tenaga Kerja Pembesian dan Bekisting Saat Jam Kerja Normal dan Lembur Menggunakan Metode Productivity Rating Caroline Maretha SUJANA \& Raka Aditya HAKIM

Analisis Faktor-Faktor yang Mempengaruhi Produktivitas Tenaga Kerja pada Proyek Pembangunan Jalan Tol Ruas Binjai-Langsa Seksi BinjaiPangkalan Brandan

Yolanda Ayu DAMAYANTI \& Mizanuddin SITOMPUL 


\section{Pengantar Redaksi}

Puji dan syukur kami sampaikan kepada Tuhan Yang Maha Esa karena atas kasih karuniaNYA kami dapat menyelesaikan penerbitan Jurnal Rekayasa Konstruksi Mekanika Sipil (JRKMS) Volume 4 Nomor 2, di bulan September tahun 2021 ini. Jurnal ini fokus pada beragam subbidang dalam Teknik Sipil antara lain Rekayasa Struktur, Rekayasa Geoteknik, Rekayasa Transportasi, Teknik Sumber Daya Air, dan Manajemen Konstruksi. Namun, tidak menutup kesempatan bagi subbidang lainnya yang berkaitan dengan keilmuan Teknik Sipil.

Satu hal yang patut disyukuri pula adalah semakin terkendalinya kondisi pandemi COVID-19 di Indonesia. Hal ini turut menjadi angin segar pendorong bagi kita untuk meningkatkan semangat meneliti dan berkontribusi pada bidang keilmuan kita. Pada edisi ini, kami menerima banyak artikel dengan topik yang menarik. Ada 8 peer-reviewed artikel yang terbit di Volume 4 Nomor 2 ini, yang mana terdiri atas 3 (tiga) artikel dalam topik Rekayasa Struktur, 1 (satu) artikel dalam topik Rekayasa Geoteknik, 2 (dua) artikel dalam topik Rekayasa Transportasi, 2 (dua) artikel dalam topik Manajemen Konstruksi.

Seiring dengan semakin tingginya tuntutan kualitas publikasi ilmiah oleh pemerintah, pada edisi ini tim editorial berusaha meningkatkan kualitas review dan penyuntingan dengan harapan semakin baik pula kapasitas kita bersama, dan kualitas artikel ilmiah yang kita terbitkan. Dewan redaksi menyampaikan apresiasi tinggi kepada para penulis yang tulisannya diterbitkan pada volume ini, atas kerja samanya merespon komentar dan rekomendasi dari tim editorial dan mitra bestari. Kami menyadari bahwa butuh dedikasi dan investasi waktu untuk menghasilkan karya tulis yang baik dan bermanfaat. Terkhusus, kami bersyukur atas para mitra bestari yang tidak pernah lelah dalam menyambut permintaan kami dengan penuh dedikasi.

Sebagai penutup, harapan kami adalah semoga jurnal ini dapat menjadi media ilmiah yang bermanfaat dan informatif bagi rekan-rekan dan praktisi bidang ketekniksipilan di Indonesia. Salam hangat dan Salam sehat.

Medan, September 2021

Tim Editorial 
